\title{
Depth and Diversity: A Reply
}

\author{
Felix Riede
}

It may sound worn but I truly appreciate the opportunity and privilege not just to present some of my thoughts in print as a Current Swedish Archaeology keynote paper, but to have so many colleagues whom I esteem highly - Poul Holm, Paul Lane, Britt Solli, Christina Fredengren, Julia Shaw, Andrew Roddick, thank you all - take the time to comment on them. All too rarely are academic conversations and debates taken into printed media. My reading of the comments overall is a positive one and this underlines the importance, urgency and relevance of the engagement of all variants of archaeology with the contemporary quandaries precipitated by climate change, the biodiversity crisis, environmental justice - the whole entangled and wicked package of human-environment relations. Paul Lane and Britt Solli, for instance, seem to strongly support my suggestion - citing a remarkable range of additional evidence and references - that archaeologists can be strong partners in moving science communication, for instance, from 'matters of fact' to 'matters of concern' (Stewart \& Lewis 20I7). While some of the commentators take issue with aspects of my perspective or rather its many lamentable omissions, I would very much like to see the collective of these comments as an expression of the lively diversity within archaeology's 'palaeo' corner of the environmental humanities. This diversity finds its concrete expression in the fact that I learned a great deal reading the comments and felt compelled to chase up numerous references cited in the comments.

This diversity also comes with drawbacks, however. No single scholar - not me, at least - can keep up with the relevant knowledge production and have qualified opinions on all dimensions of the (palaeo)environmental humanities. With this disclaimer, I do not want to absolve myself from

Centre for Environmental Humanities and Department of Archaeology and Heritage Studies, Aarhus University Email: f.riede@cas.au.dk 
any mis-readings or misrepresentations, but I do want to underscore that my paper was never intended as a comprehensive review; my predilections and experiences from attending environmental humanities conferences, interacting with environmental humanities colleagues, have all shaped my vision, have shaped my paper. Christina Fredengren charges me with neglecting, for instance, gender dimensions of environmental humanities scholarship or Derridean hauntologies and with reacting strongly - maybe too strongly - against the writings of Braidotti. She states that I miss 'the long discussions and ethics-infused scholarship within the field of Environmental Humanities which have engaged with deep time, deep pasts and futures from a much more inclusive horizon'. In a way she is quite right; there are substantial bodies of scholarship that I respect but that I also see as not entirely unproblematic. Archaeology has not played a major role in this scholarship. And much of this supposedly inclusive writing reveals what to me is a vulnerable Achilles heel of the environmental humanities, that is its occasional sliding into the more arcane reaches of the humanities where intellectual cross-references and terminologies become so opaque that, I fear at least, more people are excluded from the conversation than are included. Christina Fredengren appears to be pushing for a more radical engagement of archaeology with post-humanist intellectual currents and alternative stakeholders. In that light, I may appear as a conservative, but let me here repeat an important point easily lost in the genre of keynotes: I think that intellectual diversity is paramount and that we each should play to our strengths and the strengths of the material and evidence we wield. My strength clearly lies elsewhere than Christina Fredengren's. Her entry to the ethical dimensions of archaeological research has a different starting point compared to mine. While I may seem less concerned with the classical environmental humanities than the emerging field of geoethics (Wyss \& Peppoloni 20I5; Riede et al. 20I6; Bohle \& Marone 20I9), my interest is more precisely piqued by the observation that ethical engagements are entering environmental archaeological thinking from the environmental humanities as well as from the geosciences. I am concerned with engaging palaeoenvironmental scientists and climate and risk modelers, whom I see as stakeholders, collaborators and potential allies in making the past more relevant in policymaking precisely because they have better-established pathways in that domain (see Jackson et al. 2018). While this may seem like a conservative orientation, I am convinced that much can yet be gained from such engagements if they are conducted under the premises of an evidential and ethical awareness that is derived from the environmental humanities sensu lato.

One remarkable extension of my argument is encapsulated in Julia Shaw's powerful reminder that the environment and the environmental hu- 
manities are also emmeshed in important ways with religious worldviews, inclusive health and well-being. The power of her argument, which I fully accept, rests in no little part in the weight of evidence she brings to bear on the matter. Her particular evidential grounding in the rich textual and material sources of late prehistoric and historic South Asia provides a vivid canvas and rich contrast for reflections on Western notions of wellbeing, nature, the environment. The striking differences that emerge show that the world does not have to function following neoliberal rules of engagement; an important antidote to many hegemonic discourses on sustainability and resilience (see also Barrios 20I6). But can such thinking be integrated into novel human-environment engagements 'at home' in Europe? Given that one of my concerns is generating greater environmental engagement and action within the academy and across the many sectors with which it intersects, I wonder whether the very same difference that gives these perspectives their reflective traction, also - together with their coupled temporal, geographic and cultural distance - weakens their translation into contemporary and specifically Western discourse.

What is rather more certain is the importance of different worldviews and religions in tackling climate change impacts and disasters locally. In relation to volcanic risk mitigation, for instance, it is argued evermore strongly that such dimensions must be considered (Chester et al. 2008, 20I2; Haynes et al. 2008; Donovan 20I0; Barclay et al. 20I5); archaeology and heritage, as Julia Shaw and I would agree, have a role to play here in staging and framing such conversations. Andrew Roddick brings a perspective from across the Atlantic into play. He reminds us that many earlier archaeological approaches, for instance those under the auspices of political ecology, have tackled environmental issues. I could not agree more but this makes it all the more remarkable that archaeological scholarship has played so little part in the new wave of the environmental humanities which - while perhaps to a degree being new imperial clothes - have also generated substantial and fresh public appeal, funding traction, and intellectual creativity. I would still maintain that archaeology has a greater role to play in this movement.

Andrew Roddick also argues that empirical robusticity is essential, especially in post-truth times. We fully agree on the need for academics to carefully consider their motivations, their tools and goals. I could not agree more but would add that such concerns swiftly bring about difficult decisions with regard to our specific employment situations - after all, most universities do value publications significantly higher than public engagement - and our skill sets and time constraints. I believe that the archaeological record speaks clearly about the substantial causal role that the environment and environmental changes play in the fates of communities 
and societies. How we best react to this, how we individually contribute remains a personal decision. Activism or politics are options but they inevitably come with a price vis-à-vis our academic engagements. Furthermore, I do not think we should underestimate the potential long-term impact of working in the academy, developing and deploying novel pedagogies. Both Christina Fredengren and Andrew Roddick stress the importance of intergenerational justice and cultural transmission. Indeed, theories of cultural transmission suggest that teachers can be change agents. The called-for 'societal transformations' vis-à-vis changes in climate, environment, biodiversity can surely be assisted through teaching - also in archaeology (Riede et al. 2016). In turn, this teaching may contribute to situating universities as critical but also positive contributors in our Anthropocene future (cf. Wright 20I7). Moving ahead into deep futures will require many incremental as well as some larger-scale societal adjustments. If we are lucky, we have a sufficient number of generations to bring these into effect through cultural transmission. Speaking of the deep past, both Poul Holm and Andrew Roddick would like to see a greater elaboration of this notion. First, archaeology can serve as an evidence-based interlocutor in relation to short-term political decisions conditioned by electoral terms. The notion of 'depth' should not be understood too literally here. After all, archaeology very much operates in the recent past as well as in the temporally deep past. The real strength of a 'palaeoenvironmental humanities' approach rests in more ready interfaces, terms of reference and inclusive language between the palaeoenvironmental and palaeosocietal datasets; it also brings to this transdisciplinary table a temporally deep awareness, that even when shallow time frames are under discussion, weaves in empirical, interpretative and imaginative threads coming to us from the more distant past.

Let me provide one example by returning to volcanic and attendant hazards. Here, deeper time perspectives have, for instance, shown that the relative quiet of the last century has created an illusory 'disaster gap' (Pfister 2009) leading to policy complacency (Sparks 2007) in spite of the evident risks that major eruptions - sure to happen sooner or later - would have on contemporary society (Newhall et al. 2018; Self 2006; Papale $\&$ Marzocchi 2019), especially under conditions of dense, urban agglomerations (Scandone et al. 2015). Such threats generate existential risks that need facing (Torres 20I8; Rees 20I3), but where the lived experiences of the recent past patently fail to provide adequate resources. Archaeological datasets can contribute to shaping scenarios used in preparing for such events (Sonnek et al. 20I7; Schmidt et al. 20II; Riede 20I7), and they can also feed into exercises of empirically disciplined speculation where the genres of science-based scenario-building and climate fiction meet. Archaeology 
can assist in long-term risk communication, in 'imagining the unimaginable' (Donovan \& Oppenheimer 20I 8: I 49) - the deep and deeply entangled futures of changed climates, changed environments and changed societies.

\section{References}

Barclay, J., Haynes, K., Houghton, B.F. \& Johnston, D. 20I 5. Social Processes and Volcanic Risk Reduction. In: Sigurdsson, H., Houghton, B.F., Rymer, H., Stix, J. \& McNutt, S.R. (eds). Encyclopedia of Volcanoes, pp. I2O3-I 2I4. San Diego (CA): Academic Press.

Barrios, R.E. 20I6. Resilience: A Commentary from the Vantage Point of Anthropology. Annals of Anthropological Practice. Vol. 40, pp. 28-38.

Bohle, M. \& Marone, E. 20I9. Humanistic Geosciences and the Planetary Human Niche. In: Bohle, M. (ed). Exploring Geoethics: Ethical Implications, Societal Contexts, and Professional Obligations of the Geosciences, pp. I37-I64. Cham: Springer International Publishing.

Chester, D.K., Duncan, A.M. \& Dibben, C.J.L. 2008. The Importance of Religion in Shaping Volcanic Risk Perception in Italy, with Special Reference to Vesuvius and Etna. Journal of Volcanology and Geothermal Research. Vol. I72, pp. 216-228.

Chester, D.K., Duncan, A.M. \& Sangster, H. 20I2. Religious Interpretations of Disaster. In: Wisner, B., Gaillard, J.-C. \& Kelman, I. (eds). The Routledge Handbook of Hazards and Disaster Risk Reduction, pp. I09-I 20. Abington: Routledge.

Donovan, A. \& Oppenheimer, C. 2018. Imagining the Unimaginable: Communicating Extreme Volcanic Risk. In: Fearnley, C.J., Bird, D.K., Haynes, K., McGuire, W.J. \& Jolly, G. (eds). Observing the Volcano World: Volcano Crisis Communication, pp. I49-163. Cham: Springer International Publishing.

Donovan, K. 20I0. Doing Social Volcanology: Exploring Volcanic Culture in Indonesia. Area. Vol. 42, pp. II7-I26.

Haynes, K., Barclay, J. \& Pidgeon, N. 2008. Whose Reality Counts? Factors Affecting the Perception of Volcanic Risk. Journal of Volcanology and Geothermal Research. Vol. I72, pp. 259-272.

Jackson, R.C., Dugmore, A.J. \& Riede, F. 20I8. Rediscovering Lessons of Adaptation from the Past. Global Environmental Change. Vol. 52, pp. 58-65.

Newhall, C., Self, S. \& Robock, A. 2018. Anticipating Future Volcanic Explosivity Index (VEI) 7 Eruptions and their Chilling Impacts. Geosphere. Vol. I4, pp. 572-603.

Papale, P. \& Marzocchi, W. 2019. Volcanic Threats to Global Society. Science. Vol. 363 , p. I275.

Pfister, C. 2009. The 'Disaster Gap' of the 2oth Century and the Loss of Traditional Disaster Memory. GAIA - Ecological Perspectives for Science and Society. Vol. I8, pp. 239-246.

Rees, M. 2013. Denial of Catastrophic Risks. Science. Vol. 339, p. II23.

Riede, F. 20I7. Past-Forwarding Ancient Calamities. Pathways for Making Archaeology Relevant in Disaster Risk Reduction Research. Humanities. Vol. 6, \#79.

Riede, F., Andersen, P. \& Price, N. 20I6. Does Environmental Archaeology Need an Ethical Promise?. World Archaeology. Vol. 48, pp. 4664-468I.

Riede, F., Sørensen, A.H., Dietrich, J., Skaaning Høegsberg, M., Nordvig, M.V. \& Nielsen, E.B. 20I6. Learning from the Past: Teaching Past Climate Change and Catastrophes as 
Windows onto Vulnerability and Resilience. In: Siperstein, S., Lemenager, S. \& Hall, S. (eds). Teaching Climate Change in the Humanities, pp. I26-I35. New York, NY: Routledge.

Scandone, R., Bartolini, S. \& Martí, J. 20I 5. A Scale for Ranking Volcanoes by Risk. Bulletin of Volcanology. Vol. 78, pp. I-8.

Schmidt, A., Ostro, B., Carslaw, K.S., Wilson, M., Thordarson, T., Mann, G.W. \& Simmons, A.J. 20Ir. Excess Mortality in Europe Following a Future Laki-style Icelandic Eruption. Proceedings of the National Academy of Sciences. Vol. I08, pp. I57IO-I 57 I 5.

Self, S. 2006. The Effects and Consequences of Very Large Explosive Volcanic Eruptions. Philosophical Transactions of the Royal Society A: Mathematical, Physical and Engineering Sciences. Vol. 364, pp. 2073-2097.

Sonnek, K.M., Mårtensson, T., Veibäck, E., Tunved, P., Grahn, H., von Schoenberg, P., Brännström, N. \& Bucht, A. 20I7. The Impacts of a Laki-like Eruption on the Present Swedish Society. Natural Hazards. Vol. 88, pp. I565-I590.

Sparks, S. 2007. Use the Calm between the Storms. Nature. Vol. 450, pp. 354-354.

Stewart, I.S. \& Lewis, D. 20I7. Communicating Contested Geoscience to the Public: Moving from 'Matters of Fact' to 'Matters of Concern'. Earth-Science Reviews. Vol. I74, pp. I 22-I33.

Torres, P. 20I8. Facing Disaster: The Great Challenges Framework. Foresight. Vol. 2, pp. 4-34.

Wright, S. 20I7. Can the University be a Livable Institution in the Anthropocene?. In: Deem, R. \& Eggins, H. (eds). The University as a Critical Institution?, pp. I7-37. Rotterdam: Sense Publishers.

Wyss, M. \& Peppoloni, S. (eds). 2015. Geoethics: Ethical Challenges and Case Studies in Earth Sciences. Oxford: Elsevier. 